\title{
MENINGKATKAN KEMAMPUAN BERBICARA BAHASA INGGRIS SISWA MELALUI PEMBELAJARAN KOOPERATIF TIPE THINK PAIR-SHARE DI KELAS VII.C SMPN 1 KECAMATAN LAREH SAGO HALABAN
}

\author{
Ifriani \\ SMPN 1 Kecamatan Lareh Sago Halaban, Kabupaten Lima Puluh Kota \\ email: ifrianimpd@gmail.com
}

\begin{abstract}
This research is motivated by the existence of problems in learning English. From the teacher's perspective, teachers mostly use the mother tongue (regional language) during the teaching and learning process, preparing teaching plans, teaching media, choosing appropriate teaching methods, and having limited time to teach. Furthermore, from the students' point of view, such as problems of lack of self-confidence, limited vocabulary, minimal mastery of grammar, inappropriate word pronunciation and intonation, shame to speak English, and their low motivation. The purpose of this study was to determine the improvement of student's English speaking skills through Think Pair Share cooperative learning in class VII.C SMPN 1 Kec. Lareh Sago Halaban. This type of research is classroom action research (CAR). This PTK was held at SMPN 1 Kec. Lareh Sago Halaban. This research was conducted in semester 2 of the 2018/2019 academic year. The research subjects were class VII.C SMP Negeri 1 Kec. Lareh Sago Halaban totaling 28 students consisting of 11 male students and 17 female students. In the pre-cycle, 10 students (35.72\%) completed speaking proficiency level, while 18 students (64.28\%). In the first cycle, the level of students' speaking ability, namely 16 students $(64.28 \%)$ had been completed and 12 students $(35.72 \%)$ were declared incomplete. In the second cycle, the level of speaking ability of 24 students (85.71\%) had been completed and 4 students (14.29\%) were declared incomplete. Learning using the Think Pair Share (TPS) cooperative learning method can improve the speaking ability of class VII.C students of SMP Negeri 1 Lareh Sago Halaban.
\end{abstract}

Keywords: English speaking skill, Cooperative Learning, think pair share

\begin{abstract}
Abstrak
Penelitian ini dilatarbelakangi oleh adanya permasalahan dalam pembelajaran bahasa inggris. Dari sisi guru, guru lebih banyak menggunakan bahasa ibu (bahasa daerah) selama proses belajar-mengajar, penyusunan perencanaan mengajar, media pengajaran, memilih metoda mengajar yang tepat, dan terbatasnya waktu untuk mengajar. Selanjutnya, dari sisi siswa, seperti permasalahan kurangnya rasa percaya diri, terbatasnya kosa kata, penguasaan tata bahasa yang minim, pengucapan kata dan intonasi yang kurang tepat, malu untuk berbicara bahasa Inggris dan rendahnya motivasi mereka. Tujuan penelitian ini adalah untuk mengetahui peningkatan keterampilan berbicara bahasa Inggris siswa melalui Pembelajaran kooperatif tipe Think Pair Share di kelas VII.C SMPN $1 \mathrm{Kec}$. Lareh Sago Halaban. Jenis penelitian ini adalah penelitian tindakan kelas (PTK). PTK ini dilaksanakan di SMPN 1 Kec. Lareh Sago Halaban. Penelitian ini dilaksanakan di semester 2 tahun pelajaran 2018/2019. Subjek
\end{abstract}


penelitian adalah siswa kelas VII.C SMP Negeri 1 Kec. Lareh Sago Halaban yang berjumlah 28 siswa yang terdiri dari 11 orang laki-laki dan 17 orang siswa perempuan. Pada prasiklus tingkat kemampuan berbicara siswa yang tuntas 10 orang $(35,72 \%)$ sedangkan yang tidak tuntas 18 orang $(64,28 \%)$. Pada siklus I tingkat kemampuan berbicara siswa yaitu 16 orang siswa $(64,28 \%)$ sudah tuntas dan 12 orang siswa $(35,72 \%)$ dinyatakan belum tuntas. Pada siklus II, tingkat kemampuan berbicara 24 orang siswa $(85,71 \%)$ sudah tuntas dan 4 orang siswa $(14,29 \%)$ dinyatakan belum tuntas. Pembelajaran dengan menggunakan metode pembelajaran kooperatif tipe Think Pair Share (TPS) dapat meningkatkan kemampuan berbicara siswa kelas VII.C SMP Negeri 1 Lareh Sago Halaban.

Kata Kunci: Keterampilan berbicara bahasa inggris, Pembelajaran Kooperatif, think pair share

\section{PENDAHULUAN}

Di Indonesia, bahasa Inggris dipergunakan dan dipelajari sebagai bahasa asing mulai dari sekolah dasar (SD) hingga perguruan tinggi. Tujuan pembelajaran bahasa Inggris pada kurikulum Sekolah Menengah Pertama (SMP) bahwa setelah siswa menyelesaikan studinya, mereka diharapkan mampu berkomunikasi baik lisan maupun tulisan dengan baik. Dalam berkomunikasi mereka diharapkan tidak hanya berkomunikasi secara lisan, dalam hal ini mampu mendengar (listening) dan berbicara (speaking) dengan lancar namun mereka juga diharapkan mampu membaca (reading) teks-teks yang menggunakan bahasa Inggris dengan baik dan komunikasi dengan bahasa tulisan (writing). Jadi tujuan pengajaran bahasa Inggris di SMP adalah agar peserta didik mampu berbahasa Inggris dengan baik, lisan maupun tu lisan. Hedge (2000:54) mendefinisikan bahwa pengajaran Speaking bertujuan untuk membuat siswa agar mempunyai kemampuan dasar untuk berkomunikasi dan menguasai kemampuan akademis. Kemampuan berkomunikasi atau percakapan termasuk interaksi tatap muka dimana komunikasi tersebut berdasarkan konteks yang ada, seperti situasi yang terjadi, bahasa badan, ekspesi wajah dan intonasi.

Namun dalam proses pembelajaran bahasa Inggris, banyak permasalahan yang dihadapi siswa di sekolah. Terutama dalam keterampilan berbicara. Mereka cendrung diam kalau ditanya baik itu pada kegiatan awal, inti, maupun pada kegiatan penutup. Hanya sedikit saja peserta didik yang mau berbicara. Mereka merasa malu berbicara karena takut ditertawakan atau diejek temannya. Yang tak kalah penting masalah siswa dalm berbicara adalah siswa tidak memiliki kosa kata bahasa Inggris yang memadai untuk berbicara. Hal ini membuat mereka kurang percaya diri dalam berbicara.

Masalah lain yang harus segera dipecahkan adalah metoda dan teknik guru dalam mengajar keterampilan berbicara (speaking). Kenyataan menunjukkan bahwa metoda yang telah digunakan oleh para guru kurang tepat untuk memacu siswa berbicara bahasa Inggris secara komunikatif dan alami, sebab siswa hanya menghafal teks atau mereka-reka apa yang akan dibicarakan. Maka, guru diharapkan mampu mengatasi dan meningkatkan minat berbicara siswa. Dalam hal ini metoda dan teknik pengajaran sangatlah penting diperhatikan. Media pembelajaran juga dapat memfasilitasi siswa dalam mengeluarkan ide-ide dan kosakata dalam berbicara. 
Ada beberapa metode yang dapat digunakan untuk pengajaran bahasa Inggris untuk pemula. Salah satu diantaranya dengan menerapkan pembelajaran kooperatif. Slavin dalam Nur (2009:1) berpendapat bahwa "cooperative learning is an approach that involves a small group of learners working together as a team to solve a problem, complete a task, or accomplish a common goal". Kutipan tersebut menunjukkan bahwa pembelajaran kooperatif terpusat pada siswa, karena dalam suatu tim siswa bekerja sama untuk memecahkan suatu masalah, menyelesaikan tugas, ataupun untuk mencapai suatu tujuan tertentu. Maka dengan adanya pembelajaran kooperatif diharapkan siswa dapat bekerjasama dalam menyelesaikan permasalahan mereka dalam belajar bahasa Inggris.

Salah satu tipe dari pembelajaran kooperatif adalah dengan Think Pair Share (TPS). Pembelajaran kooperatif Think-Pair-Share melibatkan tiga langkah, seperti yang dikemukakan oleh Spencer Kagen dalam Muslimin (2000:26) yaitu: (1) Thinking (berpikir) yaitu guru mengajukan pertanyaan atau isu yang berhubungan dengan pelajaran, kemudian siswa diminta untuk memikirkan pertanyaan atau isu tersebut secara mandiri untuk beberapa saat, (2) Pairing (Berpasangan) siswa berpasangan dengan yang lain untuk mendiskusikan apa yang telah dipikirkannya pada tahap pertama, sehingga siswa dapat saling berbagi ide dalam menyelesaikan suatu persoalan, (3) Sharing (berbagi) pasangan membagikan ide dengan seluruh anggota kelas.

Think Pair Share dapat menolong siswa untuk saling berbicara dan saling berbagi ide. Think Pair Share (TPS) juga dapat menolong siswa menjalin hubungan sosial diantara mereka. Think Pair Share (TPS) dapat meningkatkan kelancaran dan kemampuan berbicara siswa. Dengan menggunakan metode ini, siswa mempunyai kesempatan berbicara. Mereka dapat mempraktekkan kemampuan berbicara mereka dengan teman secara berpasangan. Selain itu, dengan Think Pair Share (TPS) siswa lebih berani berbicara dan mengungkapkan idenya, meningkatkan partisipasi siswa dalam penggunaan bahasa. Dan juga Think Pair Share (TPS) dapat menolong siswa untuk saling menjalin persahabatan dalam kehidupan sosial mereka sehari-harinya. Menurut Anita (2002:56) pembelajaran kooperatif Think-Pair-Share memberi kesempatan kepada siswa untuk bekerja sendiri dan bekerja sama dengan orang lain, serta optimalisasi partisipasi siswa. Pembelajaran kooperatif Think-Pair-Share juga dapat memberikan lebih banyak waktu berpikir, untuk merespon, dan saling membantu. Sehingga memungkinkan siswa untuk memperoleh pengalaman belajar yang dapat meningkatkan kemampuan komunikasi dan pemecahan masalah matematika siswa.

Berdasarkan deskripsi masalah diatas peneliti sebagai guru peneliti akan melaksanakan Penelitian Tindakan Kelas Di kelas VII.C pada SMP Negeri 1 Kecamatan Lareh Sago halaban Kabupaten Lima Puluh Kota dengan judul "Peningkatan Kemampuan Berbicara Bahasa Inggris Siswa Melalui Pembelajaran Kooperatif Tipe Think Pair- Share di kelas VII.C pada SMP Negeri 1 Kecamatan Lareh Sago Halaban.

Rumusan masalah dalam penelitian ini yaitu bagaimana Peningkatan Kemampuan Berbicara Bahasa Inggris Siswa Melalui Pembelajaran Kooperatif Tipe Think Pair-Share di kelas VII.C pada SMP Negeri 1 Kecamatan Lareh Sago Halaban, Kabupaten Lima Puluh Kota. Tujuan penelitian ini adalah untuk mengetahui peningkatan keterampilan berbicara bahasa Inggris siswa melalui 
Pembelajaran kooperatif tipe Think Pair Share di kelas VII.C SMPN 1 Kec. Lareh Sago Halaban.

\section{METODOLOGI}

Jenis penelitian ini adalah Penelitian Tindakan Kelas (PTK). Penelitian tindakan kelas ini dilakukan dengan mengikuti model yang dikembangkan oleh Kemis dan Taggart (1988:11). Menurut Alwi dalam Waitlem dan Risman (2017:47) mengatakan bahwa PTK memiliki prosedur yang terdiri dari empat tahapan yaitu tahap perencanaan, pelaksanaan, pengamatan dan refleksi.

Tempat saya melakukan penelitian Tindakan Kelas ini adalah di SMP Negeri 1 Kecamatan Lareh Sago Halaban, karena saya ditugaskan untuk mengajar di SMP ini semenjak tahun 1991 sampai sekarang. Adapun pelaksanaan dari penelitian Tindakan Kelas ini akan dilaksanakan selama 3 bulan. Mulai dari bulan Maret sampai bulan Mei 2019. Penelitian ini direncanakan dilakukan dalam 3 siklus. Masing-masing siklus terdiri dari 3 kali pertemuan. Subjek penelitian adalah siswa kelas VII.C SMP Negeri 1 Kec. Lareh Sago Halaban yang berjumlah 28 siswa yang terdiri dari 11 orang laki-laki dan 17 orang siswa perempuan.

Setelah mengumpulkan data, semua data akan dianalisa dengan cara kuantitatif dan kualitatif. Prosedur pengolahan data adalah sebagai berikut:

1. Pada cara kuantitatif, semua data yang diambil dari tes speaking dihitung dengan rumus sebagai berikut. ( Depdiknas, 2006 )

$$
\begin{aligned}
& \mathrm{P}=\mathrm{F} / \mathrm{N} \\
& \mathrm{P}=\text { Prosentasi keberhasilan siswa } \\
& \mathrm{F}=\text { Jumlah Siswa yang telah mencapai kelancaran } \\
& \quad \text { berbicara } \\
& \mathrm{N}=\text { Jumlah semua siswa. }
\end{aligned}
$$

2. Kemudian, data juga akan dianalisa dengan cara kualitatif. Setelah mendapatkan data, peneliti akan menganalisa data dengan tehnik yang diajukan oleh Gay dan Airsian (2000:140). Analisa tersebut terdiri dari enam langkah dalam menganalisa data sebagai berikut: Data yang telah terkumpul akan dianalisa secara kualitatif dengan menggunakan analisis induktif. Analisis ini akan digunakan dengan memperhatikan sekelompok data dan menyusunnya dengan mengelompokkan serta menggambarkan sesuai tema. Data diambil dari lembaran observasi dan tes siswa.

3. Catatan lapangan: disini, peneliti akan membaca catatan lapangan yang telah didapatkan selama penelitian secara mendalam. Peneliti mengidentifikasi dua tema dari catatan lapangan tersebut: kegiatan siswa dan kegiatan guru.

Tindakan dalam penelitian ini dianggap berhasil apabila:

1. Lebih dari $70 \%$ siswa dapat barbicara baik spontan maupun penugasan dalam proses pembelajaran.

2. Lebih dari $70 \%$ siswa dapat mencapai sama atau lebih dari Kriteria Ketuntasan Minimal (KKM) untuk keterampilan berbicara yang telah ditetapkan diawal tahun pembelajaran 


\section{HASIL PENELITIAN DAN PEMBAHASAN}

\section{Hasil Penelitian}

\section{Deskripsi Tahap Studi awal}

Data yang diperoleh dari hasil observasi sebelum tindakan dapat dijelaskan bahwa masih banyak siswa yang belum mampu berbicara Bahasa Inggris sesuai dengan standar Kriteri Ketuntasan maksimal (KKM) berbicara Bahasa Inggris yang ditetapkan di SMP Negeri 1 Kecamatan Lareh Sago Halaban yaitu 70. Untuk menentukan seberapa rendah kemampuan berbicara bahasa Inggris siswa tersebut peneliti melakukan observasi terhadap proses pembelajaran Bahasa Ingggris di kelas VII.c SMP Negeri 1 Kecamatan Lareh Sago Halaban yang menjadi objek penelitian.

Lembaran observasi untuk tes speaking siswa ada 4 aspek penilaian yaitu kelancaran, intonasi, penampilan, serta tata bahasa yang dinilai. Berdasarkan hasil dari lembar observasi guru terhadap siswa mengenai indikator kemampuan berbicara siswa, maka dapat dilihat persentase nilai tingkat kemampuan berbicara siswa pada tabel dibawah ini

Tabel 1. Persentase hasil tingkat ketuntasan Kemampuan berbicara Siswa secara klasikal Sebelum Tindakan

\begin{tabular}{|c|l|c|c|}
\hline No & $\begin{array}{c}\text { Tingkat ketuntasan kemampuan } \\
\text { berbicara }\end{array}$ & Jumlah siswa & Persentase (\%) \\
\hline $\mathbf{1}$ & Tuntas $\geq 70 \%$ & 10 orang & $35,72 \%$ \\
\hline $\mathbf{2}$ & Tidak tuntas $\leq 70 \%$ & 18 orang & $64,28 \%$ \\
\hline & & 28 orang & $100 \%$ \\
\hline
\end{tabular}

Dari tabel diatas bahwa dari 28 orang siswa dinyatakan tingkat kemampuan berbicara dari 10 orang siswa $(35,72 \%)$ sudah tuntas dan 18 orang siswa $(64,28$

$\%)$ dinyatakan belum tuntas.

\section{Pelaksanaan Tindakan}

\section{1) Perencanaan}

Pada tahap ini peneliti menyiapkan instrument penelitian yang terdiri dari perangkat pembelajaran dan instrument pengumpulan data. Perangkat pembelajaran terdiri dari rencana pelaksanaan pembelajaran yang disusun untuk dua kali pertemuan .Instrument pengumpulan data yang digunakan adalah pengamatan (Lembar observasi) dan lembaran tes kemampuan berbicarabahasa Inggris soal test. Guru mengelompokkan siswa menjadi kelompok kecil yang terdiri dari 2 orang berdasarkan kepada hasil pre-test.

\section{2) Pelaksanaan}

\section{a.Siklus I Pertemuan ke-1 ( 23 Maret 2019 )}

Pada saat awal siklus pertama, pada pertemuan pertama, kegiatan pembelajaran dimulai dengan mengidentifikasi sifat-sifat orang yang berpedoman pada RPP-1. Sebelum Pembelajaran dimulai terlebih dahulu guru mengawali dengan pembacaan doa yang dipimpin oleh ketua kelas. Kemudian guru melanjutkan dengan mengabsen siswa secara perorangan. Setelah itu guru mengawali dengan menyebutkan sifat-sifat orang yang ada di lingkungan sekitar peserta didik. Kemudian guru memotivasi siswa dengan mengajukan pertanyaan tentang ciri-ciri seseorang atau keadaan orang yang ada di rumah, di sekolah, dan lingkungan sekitar peserta didik.Pertanyaan ini untuk membangun pengetahuan 
awal siswa serta memotivasi siswa agar bersemangat mengikuti pembelajaran. Selanjutnya guru menyampaikan tujuan pembelajaran yang hendak diajarkan.

Guru menjelaskan tentang ciri-ciri dan keadaan orang melalui demontrasi dan tanya jawab. Selanjutnya guru menjelaskan tentang teknis pelaksanaan model pembelajaran Kooperatif Tipe Think Pair Share. Guru meminta siswa memikirkan tentang sifat-sifat orang yang ada dilingkungan sekitar siswa. Kemudian guru membentuk kelompok siswa yang terdiri dari 2 siswa perkelompok dan mengutarakan hasil pemikiran mereka masing-masing.Dalam hal ini, guru bertindak sebagai fasilitator, membimbing dan mengamati siswa pada masing-masing pasangan secara berkeliling, dengan terus memberikan motivasi kepada setiap siswa terutama untuk mengembangkan ide-ide mereka. Setelah siswa selesai berdiskusi guru menyuruh siswa mempresentasikan hasil diskusi mereka tentang sifat-sifat orang yang ada dilingkungan sekitar siswa. Guru memantau kegitan siswa selama proses presentasi berlansung. Kemudian guru memberikan point kepada siswa dan pasangannya yang telah mempresentasikan hasil diskusi mereka. Selanjutnya diberi penguatan terhadap kemajuan aktivitas siswa.

Sebelum pembelajaran diakhiri, siswa diberi kesempatan untuk bertanya dan menyimpulkan pelajaran yang telah dibahas. Setelah itu guru mengadakan evaluasinya dengan menyuruh siswa menyebutkan 5 ciri-ciri seseorang yang ada dilingkungan sekitarnya.Setelah selesai, selanjutnya guru memberi tugas untuk materi berikutnya, kemudian guru menutup pelajaran.

\section{b. Siklus I Pertemuan ke-2 (28 Maret 2019)}

Pada siklus I pertemuan II kegiatan pembelajaran adalah menidentifikasi ciri-ciri binatang yang berpedoman pada RPP-1. Pembelajaran dimulai dengan pembacaan doa yang dipimpin oleh ketua kelas. Kemudian guru melanjutkan dengan mengecek kehadiran siswa secara klasikal dan mengabsen siswa secara perorangan. Setelah itu guru mengawali pembelajaran dengan menjelaskan inti materi dengan menyebutkan ciri-ciri binatang yang ada dilingkungan sekitar peserta didik. Selanjutnya guru memotivasi siswa dengan mengajukan pertanyaan tentang ciri-ciri binatang atau keadaan binatang yang ada di rumah, disekolah, dan lingkungan sekitar peserta didik.Pertanyaan ini untuk membangun pengetahuan awal siswa serta memotivasi siswa agar bersemangat mengikuti pembelajaran. Selanjutnya guru menyampaikan tujuan pembelajaran yang hendak diajarkan.

Guru menjelaskan tentang ciri-ciri dan keadaan binatang melalui demontrasi dan tanya jawab. Selanjutnya guru menjelaskan tentang teknis pelaksanaan model pembelajaran Kooperatif Tipe Think Pair Share .Guru meminta siswa memikirkan tentang ciri-ciri binatang yang ada dilingkungan sekitar siswa, Kemudian guru membentuk kelompok siswa yang terdiri dari 2 siswa perkelompok dan mengutarakan hasil pemikiran mereka masingmasing.Dalam hal ini, guru bertindak sebagai fasilitator, membimbing dan mengamati siswa pada masing-masing pasangan secara berkeliling, dengan terus memberikan motivasi kepada setiap siswa terutama untuk mengembangkan ideide mereka. Setelah siswa selesai berdiskusi guru menyuruh siswa mempresentasikan hasil diskusi mereka tentang ciri-ciri binatang yang ada dilingkungan sekitar siswa.Guru memantau kegitan siswa selama proses presentasi berlansung.. Kemudian guru memberikan point kepada siswa dan 
pasangannya yang telah mempresentasikan hasil diskusi mereka. Selanjutnya diberi penguatan terhadap kemajuan aktivitas siswa.

Sebelum pembelajaran diakhiri, siswa diberi kesempatan untuk bertanya dan menyimpulkan pelajaran yang telah dibahas.setelah itu guru mengadakan evaluasinya dengan menyuruh siswa menyebutkan 5 ciri-ciri binatang yang ada dilingkungan sekitarnya.Setelah selesai, selanjutnya guru memberi tugas untuk pembelajaran berikutnya, kemudian guru menutup pelajaran dengan membaca hamdalah.

\section{3) Observasi}

Observasi dilakukan dengan mengisi lembar observasi yang telah disediakan, mengamati aktivitas guru dan aktivitas siswa dalam mengikuti pembelajaran dengan menggunakanmodel Pembelajaran Kooperatif Tipe think pair share (TPS) setelah tindakan. Dalam penelitian ini, peneliti mengamati aktivitas guru dan aktivitas siswa selama pembelajaran berlangsung berdasarkan lembar observasi. Observasi ini juga dilakukan untuk mencocokkan pelaksanaan dengan perencanaan yang telah dibuat dan untuk mencari data hasil penerapan model Pembelajaran Kooperatif Tipe think pair share (TPS) setelah tindakan.Kekurangan pada siklus I pertemuan Idapat dilihat dari lembar observasi kegiatan guru, guru kurang memperhatikan kesiapan siswa dalam menerima pelajaran, penjelasan dalam menyampaikan kompetensi dasar dan menginformasikan model pembelajaran tipe Think Pair Share (TPS) yang akan dilaksanakan masih kurang jelas bagi siswa. Waktu yang digunakan tidak efisien, pengelolaan bahan ajar belum efektif. Sedangkan pada kegiatan siswa dapat dilihat bahwa siswa belum memberikan perhatian dan konsentrasi penuh terhadap pembelajaran. Siswa tidak mengerjakan latihan pada kelompok dengan serius,siswa masih malu untuk maju kedepan kelas. Pengambilan data hasil pembelajaran ini dengan melihat hasil tes berbicara Bahasa Inggris pada akhir pembelajaran. Berdasarkan hasil dari lembar observasi guru terhadap siswa mengenai indikator kemampuan berbicara (speaking), maka dapat dilihat persentase nilai tingkat kemampuan berbicara siswa sebagai berikut :

Dari hasil analisis, kemampuan berbicara siswa pada siklus pertama setelah proses pembelajaran menggunakan model pembelajaran kooperatif tipe Think Pair Share (TPS) kelas VII.C pada seluruh indikator dari pertemuan pertama. Dari hasil analisis diperoleh secara individual 14 orang yang mencapai ketuntasan belajar dan 14 orang yang belum mencapai ketuntasan. Sedangkan ketuntasan belajar secara keseluruhan adalah 50\% dari 28 orang siswa yang mengikuti tes. Hal ini berarti pada kelas VII.C SMPN 1 Kec.Lareh Sago Halaban sesudah menggunakan metode model pembelajaran tipe Think Pair Share (TPS) pada siklus pertama belum mencapai ketuntasan belajar secara keseluruhan. Menurut Depdiknas (2006) bahwa proses pembelajaran di kelas dikatakan tuntas secara klasikal apabila $75 \%$ siswa di kelas mendapat nilai $\geq 70$.

Hasil belajar siswa pada siklus pertama setelah proses pembelajaran menggunakan model pembelajaran kooperatif tipe Think Pair Share (TPS) kelas VII.C pada seluruh indikator dari pertemuan kedua. Dari hasil analisis diperoleh secara individual 16 orang yang mencapai ketuntasan belajar dan 12 orang yang belum mencapai ketuntasan. Sedangkan ketuntasan belajar secara keseluruhan adalah 64,28\% dari 28 orang siswa yang mengikuti tes. Hal ini berarti pada kelas VII.C SMPN 1 Kec. Lareh Sago Halaban sesudah menggunakan metode 
model pembelajaran tipe Think Pair Share (TPS) pada pertemuan kedua masih belum mencapai ketuntasan belajar secara keseluruhan. Menurut Depdiknas (2006) bahwa proses pembelajaran di kelas dikatakan tuntas secara klasikal apabila $75 \%$ siswa di kelas mendapat nilai $\geq 70$.

\section{4) Refleksi}

Pada siklusI pertemuan II kemampuan bahasa inggris siswa sudah mulai meningkat walau masih rendah.Kekurangan pada siklus I pertemuan II adalah guru masih kurang memperhatikan kesiapan siswa menerima pelajaran, maka guru perlu lebih memperhatikan kesiapan siswa dalam menerima pelajaran. Selanjutnya penjelasan dalam menyampaikan kompetensi dasar dan menginformasikan model pembelajaran tipe Think Pair Share (TPS) yang akan dilaksanakan masih kurang jelas, pengelolaan waktu dalam diskusi dan presentasi belum maksimal sehinga waktu untuk presentasi pada pertemuan pertama tidak cukup. Motivasi siswa sudah mulai tumbuh dengan model pembelajaran tipe Think Pair Share (TPS), aktvitas siswa sudah mulai terlihat meskipun belum maksimal karena siswa belum paham dengan model pembelajaran tipe Think Pair Share (TPS) ,masih adanya siswa yang tidak mengerjakan latihan dengan serius, kemampuan mempresentasekan belum merata kesetiap pasangan. Semua kekurangan dan kelemahan yang terdapat pada pertemuan kedua dijadikan acuan dan tolak ukur pelaksanaan siklus II pertemuan I.

\section{c. Siklus II}

\section{1) Perencanaan}

Pada tahap ini peneliti menyiapkan instrument penelitian yang terdiri dari perangkat pembelajaran dan instrumen pengumpulan data.Perangkat pembelajaran terdiri dari rencana pelaksanaan pembelajaran yang disusun untuk dua kali pertemuan dalam satu siklus.Instrument pengumpulan data yang digunakan adalah pengamatan (Lembar observasi) dan seperangkat tes hasil belajar matemátika soal test.

\section{2) Pelaksanaan}

Siklus II pertemuan I dilaksanakan pada tanggal 15 April 2019. Pada siklus II pertemuan I kegiatan pembelajaran adalah menidentifikasi ciri-ciri benda yang berpedoman pada RPP-1. Pembelajaran dimulai dengan pembacaan doa yang dipimpin oleh ketua kelas .Kemudian guru melanjutkan dengan mengecek kehadiran siswa secara klasikal dan mengabsen siswa secara perorangan. Setelah itu guru mengawali pembelajaran dengan menjelaskan inti materi dengan menyebutkan ciri-ciri benda yang ada dilingkungan sekitar peserta didik. Selanjutnya guru memotivasi siswa dengan mengajukan pertanyaan tentang ciriciri benda atau keadaan benda yang ada di rumah ,disekolah, dan lingkungan sekitar peserta didik.Pertanyaan ini untuk membangun pengetahuan awal siswa serta memotivasi siswa agar bersemangat mengikuti pembelajaran. Selanjutnya guru menyampaikan tujuan pembelajaran yang hendak diajarkan.

Guru menjelaskan tentang ciri-ciri dan keadaan benda melalui demontrasi dan tanya jawab. Selanjutnya guru menjelaskan tentang teknis pelaksanaan model pembelajaran Kooperatif Tipe Think Pair Share .Guru meminta siswa memikirkan tentang ciri-ciri benda yang ada dilingkungan sekitar siswa, Kemudian guru membentuk kelompok siswa yang terdiri dari 2 siswa perkelompok dan mengutarakan hasil pemikiran mereka masing-masing. Dalam 
hal ini, guru bertindak sebagai fasilitator, membimbing dan mengamati siswa pada masing-masing pasangan secara berkeliling, dengan terus memberikan motivasi kepada setiap siswa terutama untuk mengembangkan ide-ide mereka. Setelah siswa selesai berdiskusi guru menyuruh siswa mempresentasikan hasil diskusi mereka tentang ciri-ciri benda yang ada dilingkungan sekitar siswa.Guru memantau kegitan siswa selama proses presentasi berlansung. Kemudian guru memberikan point kepada siswa dan pasangannya yang telah mempresentasikan hasil diskusi mereka. Selanjutnya diberi penguatan terhadap kemajuan aktivitas siswa.

Sebelum pembelajaran diakhiri, siswa diberi kesempatan untuk bertanya dan menyimpulkan pelajaran yang telah dibahas.setelah itu guru mengadakan evaluasinya dengan menyuruh siswa menyebutkan 5 ciri-ciri benda yang ada dilingkungan sekitarnya.Setelah selesai, selanjutnya guru memberi tugas untuk dipelajari berikutnya, kemudian guru menutup pelajaran dengan membaca hamdalah.

Pada siklus II pertemuan II kegiatan pembelajaran adalah menggunakan pemakaian to be dalam adjective yang berpedoman pada RPP. Pembelajaran dimulai dengan pembacaan doa yang dipimpin oleh ketua kelas .Kemudian guru melanjutkan dengan mengecek kehadiran siswa secara klasikal dan mengabsen siswa secara perorangan. Setelah itu guru mengawali pembelajaran dengan menjelaskan inti materi dengan menyebutkan jenis-jenis to be dan pemakaian nyaserta menyebutkan kata-kata sifat. Selanjutnya guru memotivasi siswa dengan mengajukan pertanyaan tentang to be (are, am, is). Pertanyaan ini untuk membangun pengetahuan awal siswa serta memotivasi siswa agar bersemangat mengikuti pembelajaran. Selanjutnya guru menyampaikan tujuan pembelajaran yang hendak diajarkan.

Guru menjelaskan tentangpemakaian to be dalam kata sifat melalui demontrasi dan tanya jawab. Selanjutnya guru menjelaskan tentang teknis pelaksanaan model pembelajaran Kooperatif Tipe Think Pair Share. Guru meminta siswa memikirkan tentang to be dan kata sifat yang mereka ketahui, Kemudian guru membentuk kelompok siswa yang terdiri dari 2 siswa perkelompok dan mengutarakan hasil pemikiran mereka masing-masing.Dalam hal ini, guru bertindak sebagai fasilitator, membimbing dan mengamati siswa pada masing-masing pasangan secara berkeliling, dengan terus memberikan motivasi kepada setiap siswa terutama untuk mengembangkan ide-ide mereka. Setelah siswa selesai berdiskusi guru menyuruh siswa mempresentasikan hasil diskusi mereka tentang pemakaian to be dalam kata sifat dan subjek yang digunakan untuk masing-masing to be.Guru memantau kegitan siswa selama proses presentasi berlansung. Kemudian guru memberikan point kepada siswa dan pasangannya yang telah mempresentasikan hasil diskusi mereka. Selanjutnya diberi penguatan terhadap kemajuan aktivitas siswa.

Sebelum pembelajaran diakhiri, siswa diberi kesempatan untuk bertanya dan menyimpulkan pelajaran yang telah dibahas.setelah itu guru mengadakan evaluasinya dengan menyuruh siswa menyebutkan 5 kalimat dengan menggunakan to be dan kata sifat Setelah selesai, selanjutnya guru memberi tugas untuk pembelajaran berikutnya, kemudian guru menutup pelajaran dengan membaca hamdalah.

\section{3) Observasi}


Observasi dilakukan dengan mengisi lembar observasi yang telah disediakan, mengamati aktivitas guru dan aktivitas siswa dalam mengikuti pembelajaran dengan menggunakanmodel Pembelajaran Kooperatif Tipe think pair share (TPS) setelah tindakan. Dalam penelitian ini, peneliti mengamati aktivitas guru dan aktivitas siswa selama pembelajaran berlangsung berdasarkan lembar observasi.Observasi ini juga dilakukan untuk mencocokkan pelaksanaan dengan perencanaan yang telah dibuat dan untuk mencari data hasil penerapan model Pembelajaran Kooperatif Tipe think pair share (TPS) setelah tindakan. Kekurangan pada siklus IIpertemuan I sudah mulai teratasi walaupun sedikitdapat dilihat dari lembar observasi kegiatan guru, pengelolaan bahan ajar sudah mulai efektif, guru sudah memperhatikan kesiapan siswa dalam menerima pelajaran, penjelasan dalam menyampaikan kompetensi dasar dan menginformasikan model pembelajaran tipe Think Pair Share (TPS) yang akan dilaksanakan sudah semakin jelas bagi siswa. Siswa sudah mulai tertarik dan serius mengerjakan latihan dengan kelompoknya. Pengambilan data hasil pembelajaran ini dengan melihat hasil tes berbicara Bahasa Inggris pada akhir pembelajaran.

Berdasarkan hasil dari lembar observasi guru terhadap siswa mengenai indikator kemampuan berbicara (speaking), maka dapat dilihat persentase nilai tingkat kemampuan berbicara Bahasa Inggris siswa yaitu pada siklus II pertemuan I setelah proses pembelajaran menggunakan model pembelajaran kooperatif tipe Think Pair Share (TPS) kelas VII.C pada seluruh indikator dari pertemuan kedua siklus II. Dari hasil analisis diperoleh secara individual 20 orang yang mencapai ketuntasan belajar dan 8 orang yang belum mencapai ketuntasan. Sedangkan ketuntasan belajar klasikal adalah $75 \%$ dari 28 orang siswa yang mengikuti tes. Hal ini berarti pada kelas VII.C SMPN 1 Kec. Lareh Sago Halaban sesudah menggunakan model pembelajaran tipe Think Pair Share (TPS) pada siklus II pertemuan ke-1 masih belum mencapai ketuntasan belajar secara keseluruhan.

Dari tabel diatas dianalisis ketuntasan hasil belajar siswa pada siklus II pertemuan II setelah proses pembelajaran menggunakan model pembelajaran kooperatif tipe Think Pair Share (TPS) kelas VII.C pada seluruh indikator dari pertemuan kedua siklus II. Dari hasil analisis diperoleh secara individual 24 orang yang mencapai ketuntasan belajar dan 4 orang yang belum mencapai ketuntasan. Sedangkan ketuntasan belajar klasikal adalah 85,71\% dari 28 orang siswa yang mengikuti tes. Hal ini berarti pada kelas VII.C SMPN 1 Kec.Lareh Sago Halaban sesudah menggunakan model pembelajaran kooperatif tipe Think Pair Share (TPS) pada siklus sudah mencapai ketuntasan belajar secara keseluruhan.

\section{4)Refleksi}

Pada siklus II pertemuan ke-1 ini,masih terdapat kekurangan yang menyebabkan kemampuan berbicara bahasa Inggris siswa belum mencapai target yang telah tetapkan. Kekurangan pada siklus II pertemuan ke-1 dapat dilihat dari lembar observasi kegiatan guru, kekurangan tersebut adalah pada saat membagi siswa dalam kelompok tidak merata dan masih kurang teratur, maka dalam hal ini guru perlu memberikan bimbingan yang lebih pada saat pembentukan kelompok.

Guru belum maksimal dalam membimbing dan mengontrol siswa untuk melatih keterampilan berbicara dengan benar sehingga tidak semua siswa yang bisa berbicara dalam bahasa Inggris. Dalam hal ini guru perlu memberikan motivasi kepada siswa sehingga siswa terbiasa dalam berbicar dan mau berbicara 
dengan guru atautemannya. Untuk itu akan dilakukan perbaikan pada siklus II pertemuan ke-2 dengan memanfaatkan waktu sebaik-baiknya.

Pada siklus II pertemuan kedua ini motivasi dan aktivitas siswa dalam proses pembelajaran ada kenaikan dibanding siklus II pertemuan pertama ,kerja sama dalam menjawab pertanyaan guru maupun presentase sudah baik dan siswa senang dan paham dengan penerapan model pembelajaran kooperatif tipe Think Pair Share (TPS). Secara klasikal kegiatan pembelajaran pada pertemuan kedua siklus II sudah tuntas, karena ketuntasan pada siklus ke II pertemuan kedua sudah mencapai $80 \%$ dan sudah mencapai target yang diinginkan peneliti.

Dari proses pembelajaran diatas maka pada siklus II sesudah penerapan model pembelajaran kooperatif tipe Think Pair Share (TPS) siswa sudah mencapai ketuntasan belajar yang diinginkan oleh peneliti baik individual maupun klasikal, dan pada siklus II dapat dikatakan sebagai hasil yang baik karena telah mencapai standar yang telah ditetapkan.

\section{Pembahasan}

Dalam proses pembelajaran sebelum tindakan, interaksi antara guru dengan siswa kurang optimal, hanya ada beberapa orang yang mau bertanya dan menanggapi materi pelajaran yang diberikan oleh guru. Pada siklus I, interaksi antara guru dengan siswa agak meningkat, hal ini dapat dilihat dari cara siswa menerima pelajaran dari guru. Pada siklus II, interaksi antara guru dengan siswa lebih meningkat, hal ini terihat dari semakin aktifnya siswa belajar.

Perbandingan hasil analisis kemampuan berbicara bahasa Inggris Siswa pada Siklus 1 dan 2, dapat dilihat pada table dibawah ini

Tabel 2. Hasil Analisis Rata-rata Kemampuan berbicara Bahasa Inggris siswa pada siklus 1 dan siklus 2

\begin{tabular}{|l|c|c|}
\hline \multicolumn{1}{|c|}{ Hasil Analisis } & Siklus 1 & Siklus 2 \\
\hline Rata-rata & 72,50 & 78,62 \\
\hline Persentase diatas KKM & 57,14 & 80,35 \\
\hline
\end{tabular}

Ketuntasan hasil rata-rata siswa sebelum tindakan adalah 37,72, pada siklus I nilai rata-ratanya adalah 72,50 pada siklus II nilai rata-ratanya adalah 78,62 Dari hasil rata-rata yang diperoleh dapat diketahui bahwa setelah penggunaanmodel pembelajaran kooperatif tipe Think Pair Share (TPS) pada setiap pergantian siklus, hasil rata-rata siswa mengalami peningkatan.

Sedangkan ketuntasan belajar siswa secara klasikal sebelum tindakan adalah sebesar $59,10 \%$ pada siklus I pertemuan pertama 50 pertemuan kedua 64,26\%, rata-rata ketuntasan Siklus I sebesar $57,14 \%$, pada siklus II pertemuan pertama $75 \%$, pertemuan kedua $85,71 \%$ dan rata rata ketuntasan ada siklus II sebesar $80,35 \%$, dari hasil belajar siswa secara klasikal yang diperoleh dapat diketahui bahwa dengan menggunakan model pembelajaran kooperatif tipe Think Pair Share (TPS) setiap pergantian siklus, hasil rata-rata siswa mengalami peningkatan.

Berdasarkan hasil analisis data di atas dapat disimpulkan bahwa rata-rata kemampuan berbicara siswadengan penerapan model pembelajaran kooperatif tipe Think Pair Share (TPS) secara umum lebih baik dari pada hasil belajar bahasa Inggris tanpa penerapan model pembelajaran kooperatif tipe Think Pair Share ( TPS ) Hasil belajar bahasa Inggrissiswa dalam pembelajaran semakin baik . Hal 
ini menunjukkan bahwa penerapan model pembelajaran kooperatifTipe Think Pair Share (TPS )dapat meningkatkan kemampuan berbicara bahasa Inggris siswa di kelas VII.C SMP Negeri1 Kecamatan Lareh Sago Halaban.

\section{KESIMPULAN DAN SARAN}

Berdasarkan hasil penelitian dan pembahasannya, maka peneliti dapat menyimpulkan hasil penelitian, sebagai berikut

1. Pembelajaran dengan menggunakan metode pembelajaran kooperatif tipe Think Pair Share (TPS) dapat meningkatkan kemampuan berbicara siswa kelas VII.C SMP Negeri 1 Lareh Sago Halaban. Hal ini terlihat adanya peningkatan aktivitas siswa untuk setiap siklusnya. Peningkatan aktivitas siswa dapat dilihat pada lembar observasi. Setiap siklusnya sebagian besar mengalami peningkatan.

2. Berdasarkan hasil observasi terhadap aktivitas siswa dan guru selama pembelajaran berjalan dengan baik sehingga siswa senang dan termotivasi dalam belajar Bahasa Inggris. Pembelajaran kooperatif tipe Think Pair Share (TPS) terbukti dapat meningkatkan aktivitas pembelajaran bahasa Inggris di kelas. Siswa menggunakan waktu yang tersedia selama pembelajaran untuk belajar aktif, berdiskusi antar siswa, mengemukakan jawaban dengan tanggung jawab.

3. Respon dan sikap siswa terhadap pembelajaran kooperatif tipe Think Pair Share (TPS) positif. Hal ini terbukti dari hasil tes siswa, atau ketuntasan hasil belajar siswa dalam pembelajaran bahasa Inggris meningkat.

Berdasarkan uraian kesimpulan tersebut, maka peneliti perlu mengemukakan saran yang bertujuan untuk perbaikan pada pembelajaran Bahasa Inggris selanjutnya. Adapun sarannya sebagai berikut:

1. Guru harus mempunyai pengetahuan dan keterampilan dalam menyusun instrumen pembelajaran dan menerapkan pendekatan atau model pembelajaran di sekolah. Sebab dengan referensi model dan pendekatan guru dapat memvariasikan kegiatan belajar mengajar yang pada akhirnya dapat menarik minat belajar siswa terhadap pembelajaran Ilmu Pengetahuan Alam salah satunya pembelajaran kooperatif tipe Think Pair Share (TPS).

2. Seorang guru harus bervariasi menggunakan metode pembelajaran untuk menghindari kejenuhan siswa.

3. Seorang guru harus selalu aktif melibatkan siswa selama kegiatan pembelajaran berlangsung dengan model pembelajaran koopreatif Tipe Think Pair Share (TPS). siswa dapat aktif dalam belajar;

4. Model pembelajaran kooperatif tipe Think Pair Share (TPS) dapat meningkatkan aktivitas siswa dalam belajar dan menumbuhkan rasa tanggung jawab siswa.

5. Model Pembelajaran kooperatif tipe Think Pair Share (TPS) dapat dikembangkan dan diterapkan pada standar kompetensi yang lain.

\section{DAFTAR PUSTAKA}

Anita Lie. 2002. Cooperative Learning : Mempraktikkan Cooperative Learning di Ruang-Ruang Kelas. Jakarta: PT. Gramedia Widiasarana Indonesia.

Depdiknas. 2006. Kurikulum Tingkat Satuan Pendidikan. Jakarta: Depdiknas. 
Gay, L.R and Airasian. Peter. 2000. Educational Research: Competencies for Analysis and Application. New York: Merril Publishing Company

Kemmis, Stephen (ed). 1988. The Action Research Planner $\left(3^{\text {rd }} \mathrm{ed}\right)$. Victoria: Deakin University.

Muslimin Ibrahim, dkk. 2000. Pembelajaran Kooperatif. Surabaya: UNESA Press.

Nur Asma. 2009. Model Pembelajaran Kooperatif. Padang : UNP Press

Waitlem, M.Pd dan Risman.M.Pd. 2017. Praktik Praktis Penulisan Karya Tulis Ilmiah untuk guru. Padang: Kabarita Padang. 